\title{
Dyadic relationships and power within a supply network context
}

\author{
Anni-Kaisa Kähkönen* \\ Lappeenranta University of Technology, School of Business \\ P.O. Box 20, FI-53851 Lappeenranta Finland \\ e-mail: anni-kaisa.kahkonen@lut.fi \\ Katrina Lintukangas \\ Lappeenranta University of Technology, School of Business \\ P.O. Box 20, FI-53851 Lappeenranta Finland \\ e-mail: katrina.lintukangas@lut.fi
}

\begin{abstract}
Recently in supply management research, the power theme has gained growing interest. The analysis of power in the context of dyadic relationship between a buyer and supplier has been criticized for having a limited viewpoint because it fails to explain multiple interactions. Power is a socially embedded phenomenon and, therefore, the transactions and relationships included in supply networks should also be taken under scrutiny. Thus, the aim of this study is to analyze the impact of network effects and the influence of power on the nature of collaboration between buyers and suppliers within a supply network. The case study analyzes the issue in the Finnish food industry. The results show that the power relations have an influence on the nature of the relationship, and the sources of power that are based on the network effects may crucially determine the power position of the network actor and, moreover, the power relation between two actors.
\end{abstract}

Keywords: : power, collaboration, buyer-supplier relationship, supply network

\section{Introduction}

The power theme has gained interest in supply management, while the ongoing trend is outsourcing and concentration on core competences and capabilities. Many studies have focused on the analysis of power in dyadic buyer-supplier relationship. However, Stannack (1996) argues that the perspective adopted in studies in which power is analyzed in the context of interaction relationships between the buyer and supplier is too limited in that it fails to explain multiple interactions. Power is socially embedded, and the transactions and relationships that are embedded in networks should therefore also be considered.
Zolkiewski (2001) suggested that power is the central force in a network and thereby affects the struggle for control over resources, the dynamics of the net, and the tension between collaboration and competition. According to Cendon and Jarvenpaa (2001), the role of power in a network is evident in terms of its impact on the strategic choices, governance structures, relative dependence, resources and activities performed. Thus, the issue of power is highly relevant to the discussion on networks. In order to analyze power in a sufficiently extensive context the network approach is adopted in this study, and buyers and suppliers are seen as network actors.

*Corresponding Author 
Harland (1996) has determined that research in supply chain management can be divided into four levels, which are the internal chain, dyadic relationship, external chain and network. According to Anderson et al. (1994), in order to understand buyer-supplier relationships, greater attention must be directed to the embedded context within which dyadic relationships take place. The conditions for efficiency and effectiveness in a single supply chain are determined by the way activities and resources are related to those in other chains, and this calls for a network perspective (Gadde \& Håkansson, 2001). Networks are much more complex systems than dyadic relationships or chains and, hence, there are several influencing factors that are characteristic only of networks. These so-called network effects have powerful influence, for example, on the relationships embedded in networks. Andersen and Christensen (2005) have stated that despite the growing awareness of the management of supply networks, little is known about the dynamics of such networks and how it affects the position and roles of individual actors.

Therefore, this study extends the discussion of traditional buyer-supplier relationships by emphasizing a wider network perspective in which the network effects, relations and the complicated nature of collaboration are highlighted. The aim of this study is to examine dyadic relationships between buyers and their suppliers and, moreover, power relations, particularly in the network context. Thus, the following research questions are addressed: What is the impact of network effects on power relations and how power position in a network affects the nature of collaboration between a buyer and supplier? These issues are worth studying given the need to understand the effects of networks for buyer-supplier power relations.

\section{Power in Buyer-Supplier Networks}

The concept of power can be understood and defined in many ways depending on the context. Various distinctions have been made, such as between structural and behavioral power, power sources and uses, and the macro and micro perspectives. The behavioral (i.e. micro) perspective focuses on individual actions and the exercise of power, whereas the structural (i.e. macro) perspective focuses on its sources (Cendon \& Jarvenpaa, 2001). According to Cendon and Jarvenpaa (2001), from the structural perspective power is derived not from the actions of people but from organizational structures, which include resources, interconnections and organizational positions. In this study power is analyzed in terms of network structures and positions and, hence, the structural perspective is utilized. Power can be defined as the ability to influence (Mohr et al., 1996), the ability of a firm to affect the decision-making and/or behavior (Wilkinson, 1996), the ability to manage the perceptions of the other party (French \& Raven, 1959), or as the ability of an actor to impose its will on others (Blau, 1964). Power is defined in this study as the ability to influence the decision-making and the actions of the other party. This definition is used because it fits in with the structural perspective of power.

\subsection{Power positions in networks}

Many authors have studied sources of power in buyer-supplier relationships and networks (Bates \& Slack, 1998; Cox et al. 2001; Doz \& Hamel, 1998; Porter, 1985; Ramsay, 1996; Stannack, 1996; Thorelli, 1986). From the perspective where dyadic relationships are discussed in the network context, it can be argued that the distinction can be drawn between primary and secondary sources of power. Primary sources refer to power determinants within a dyadic relationship and are only related to a certain relationship. Secondary sources refer to power sources which are caused by network effects and are therefore related to other network participants beyond the dyadic relationship. Secondary sources of power may even be more important than the primary ones if they crucially determine the power position of the network actor and, moreover, the power relation between two actors.

Given the importance to understand the meaning of these secondary power sources or network effects, the network positions should be discussed. According to Andersen and Christensen (2005), the concepts of network position and network role are complementary and, to some extent, dialectical concepts. Anderson et al. (1998) have found that position locates the actor in the relationship system relative to other actors, and role, on the other hand, is what the actor does in relation with other actors. 
Position is dependent on the role, and as stated by Håkansson (1986), the role depends on the activities the actors perform or control, the resources they manage, and the knowledge they have about the activities, resources and other actors in the network, all of which define their network positions.

According to Wilkinson and Young (2002), a network position refers to the firm's role and how it is linked directly and indirectly to the other firms in the network. Gadde et al. (2003) further suggest that the potential to influence others is a function of the company's network position, and is defined in terms of the characteristics of its relationships. The power position in a network is defined in this study, in accordance with the above, as a combination of the role the actor has in a network and the relationships it has with the other network actors. This definition supports the assumptions behind the structural perspective of power.

\subsection{The influence of power relations on buyer-supplier collaboration}

Companies are part of larger entities involving relationships to others because resources and activities are tied to the resources and activities in other firms (Gadde et al., 2003). According to van Weele and Rozemeijer (1999), attempts to forge partnership relationships often fail due to a lack of understanding of the power positions of the parties involved. Cox (2007) stated that power is one of the major factors that determine outcomes in many business transactions. Figure 1 illustrates the situations of buyer-supplier power and collaboration. It shows that when both parties are in balanced power positions, collaboration is possible because the circumstances support collaboration. Figure 1 is supported by the assumptions of Ahtonen (2008), Ahtonen et al. (2008), Batt and Purchase (2004) and van Weele and Rozemeijer (1999) who argued that if the actors are unequal in power, the one with the dominant position may not be willing to commit to collaboration. In this study their assumptions are shared and, therefore, it could be argued that the power positions strongly affect the character and depth of the relationship. Also, Veludo et al. (2006) have found that hierarchical (non-collaborative) relationships develop when one actor has a larger degree of power over another.
Figure 1. Power between the buyer and supplier

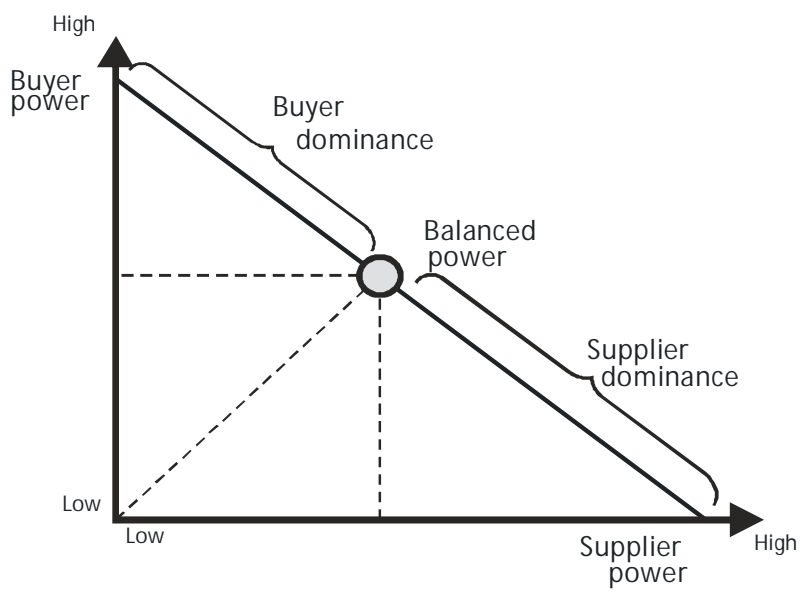

This assumption can be developed further by adding the network effects to the phenomenon of buyer-supplier dyad and power. Veludo et al. (2006) have stated that the relationships in networks are being influenced by the network effects that flow through the network. Blankenburg Holm, Eriksson and Johanson (1996) have found that network connections contribute to a single relationship (see also Blankenburg Holm, Eriksson \& Johanson, 1999; Halinen \& Törnroos, 1998). Dubois and Fredriksson (2008), in turn, stress the need to understand how one dyad in a triad affects the other dyads, and the same rationale applies to networks in which one dyad may affect the others. Furthermore, according to Batt and Purchase (2004), collaboration in networks is highly dependent on the network structure and network position which determine how collaboration will occur in the network and between which actors collaboration will take place. Hence, the actor's network role and position may be crucial when determining the power relations. If actors are in balanced power positions based on their primary sources of power, the sources of power that are dependent on the network may crucially determine the power relation in favor of one party. If for example the buyer has a much more significant role and position in the network than the supplier, this may increase the buyer's power and decrease its willingness to collaborate. In this case the network effects are in a key role because they move the power situation in the way that one party gains a more powerful position in relation to the other one. 


\section{Research Setting and Methodology}

The case study concerns the power relations and collaboration between buyers and suppliers in a certain network in the Finnish food industry. The food industry offers an interesting research context because there are many power imbalanced relationships in the food industry worldwide (Collins \& Burt, 1999; Hingley, 2001; Hingley \& Hollingsworth, 2003; Kumar, 1996 and 2005; Ogbonna \& Wilkinson, 1996; Robson \& Rawnsley, 2001). The case network comprises several actors, and the four main ones were selected as the case companies. They were selected because they represent different nodes of the network, they are significant actors in the Finnish food industry, and analyzing them will produce a complete picture of the network in question. Furthermore, it is relevant to the aim of the study that they have different roles, power positions and relationships.

In Finland there are only four main retail specialists, one of which is the Retailer of this study. In practice it has only one major domestic competitor because the other two are much smaller. The Manufacturer is one of Finland's leading food manufacturers and a market leader in many of its operational areas. Because of its long history and traditions it possesses indispensable knowledge about fresh ready-prepared food and has a wellknown brand. The Manufacturer purchases both basic and customized raw materials from Supplier $\mathrm{A}$ and the Retailer purchases end products from it.

Figure 2. The case network and the relationships

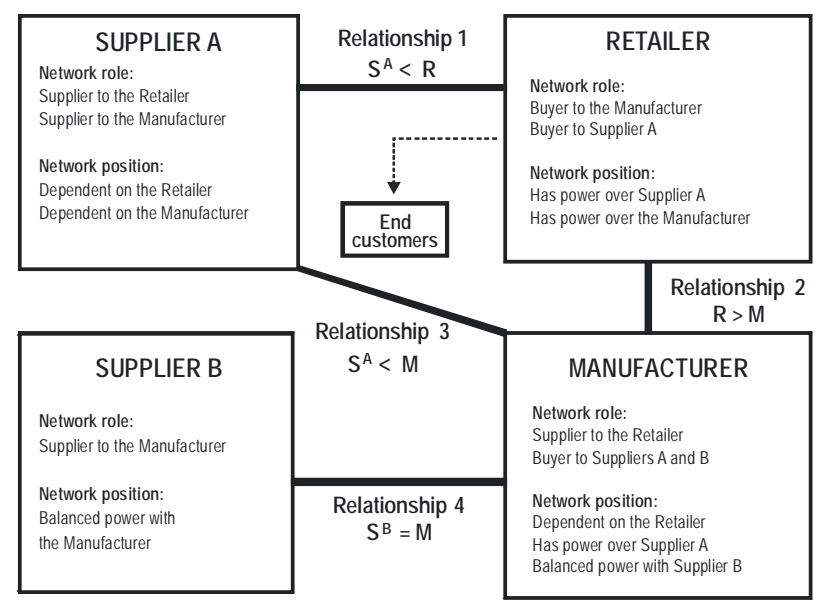

Supplier A, which is a market leader in pasta products in Finland, also manufactures flour, flakes, grits, deep-frozen dough and pastry. Supplier B, on the other hand, has indispensable know-how in food packaging, and it supplies packaging materials and solutions to the Manufacturer.

Figure 2 shows the case network, the roles and positions of the case companies and the buyersupplier relationships which are embedded in the network. Suppliers A and B are always in the role of supplier in the case network. The Retailer, on the other hand, is always in the role of buyer: it only has a supplier role when it sells end products to its end customers. The Manufacturer, however, has the roles of both buyer and supplier. It is a buyer when it purchases raw materials and packaging materials from suppliers A and B, and a supplier when it sells its end products to the Retailer. These roles are defined on the basis of their exchange relationships to each other (see Figure 2). It should be noted, however, that suppliers A and B do not currently have an exchange relationship and they are not competitors. Furthermore, Supplier B does not have an exchange relationship with the Retailer because it does not supply it with anything directly; it only supplies to the Manufacturer, which supplies to the Retailer.

\subsection{Research method and data collection}

The case method was used to study the phenomenon of buyer-supplier relationship in the network context. The study is thus an embedded single-case study with multiple units of analysis. The main argument in favor of the method (Yin, 2003) here is that the research problem is complex in nature because it includes many variables and concepts that are not easily grasped in a quantitative study. Furthermore, because the empirical research context is a contemporary event, there are multiple sources of evidence. The case study method was chosen because of the nature of the research topic and context. Given the purpose of the study to achieve a deeper understanding of collaboration and power, it was considered the most appropriate option.

Yin (2003) suggests that multiple sources of evidence should be used to establish validity and reliability, and according to Dubois and Araujo (2007), the use of multiple respondents makes it possible to 
capture a variety of perceptions and meanings, which is vital to the understanding of complex relationships. Furthermore, having numerous and highly knowledgeable informants who view the phenomena from diverse perspectives limits the interview bias (Eisenhardt \& Graebner, 2007). Hence, several informants, data from different sources and investigator triangulation were used in this study. The study comprises 29 semi-structured interviews conducted with the case companies' personnel. Data on sales and purchases was used in combination with the interview data. The research informants were selected based on their active involvement in buyersupplier relationships, supply management and marketing. The interviewees from the buyer companies mostly represented the supply management side (purchasing directors, supply managers, buyers), whereas those in marketing and selling (marketing director, customer director, sales manager) represented companies in the supplier role. In order to obtain additional information and complementary perspectives, interviews were conducted with informants from other company levels and in other positions (CEOs, commercial directors, quality manager).

A total of 16 interviews were conducted in the Manufacturer company, 6 with the Retailer, 5 with Supplier A and 2 with Supplier B (see Table 1). The number of interviews with the Manufacturer was higher than in the other case companies because the Manufacturer is the focal company of this network, it is both in the buyer and supplier role, and is involved in three relationships. The Retailer and Supplier A are both involved in two relationships, and Supplier B only in one relationship. Hence, the point at which new interviews did not provide new evidence was reached with a smaller number of interviews in the other case companies. The interview questions covered the roles and capabilities of the firms, their power positions and sources of power, relationships and information sharing. Notes were taken and the interviews were audio-recorded. The recordings were transcribed literally, producing 375 pages of data. The resulting qualitative data was coded based on interview themes, and subjected to classification and qualitative content analysis. The coding and analyses were done manually by the authors. The similarities and differences between the cases were compared by using cross-case analysis. Finally, the data was compared with the theoretical study and interfaces were sought.

\section{Findings From the Finnish Food Industry}

\subsection{Relationship 1: Retailer and Supplier A}

The Retailer is the biggest case company in terms of turnover and the number of employees, and its market power and purchasing power are remarkable sources of power for it. The Retailer's turnover is a hundred times higher than that of Supplier A and its purchases from Supplier A represent less than one per cent of its turnover, whereas the Supplier's sales to the Retailer represent one fifth of its turnover. Table 2 shows the power relation and sources of power in this relationship in which the Retailer is in a buyer role.

This relationship represents a pure arm's length relationship based on a competitive strategy. The Retailer's sources of power are so remarkable that Supplier A does not have any kind of power towards it. The only source of power that Supplier A has is its well-known brand. However, the Retailer has

Table 1. Interview information.

\begin{tabular}{|l|c|c|c|c|}
\hline Case Company & Number of Interview & Number of Interviewees & Number of Relationship & $\begin{array}{c}\text { Company's role in the } \\
\text { network }\end{array}$ \\
\hline Manufacturer & 16 & 7 & 3 & Buyer, Supplier \\
Retailer & 6 & 4 & 2 & Buyer \\
Supplier A & 5 & 1 & 2 & Supplier \\
Supplier B & 2 & 1 & 1 & Supplier \\
\hline Total & 29 & 13 & & \\
\hline
\end{tabular}


Table 2. Power relation between the Retailer and Supplier $A$

\begin{tabular}{|c|c|c|c|}
\hline Relationship 1 & Power Situation & Buyer Power Sources & Supplier Power Sources \\
\hline Retailer>Supplier A & Buyer dominance & $\begin{array}{l}\text { Market power, size } \\
\text { Control of the distribution channel } \\
\text { Amount of purchases } \\
\text { Customer preference knowledge } \\
\text { Network position, network role } \\
\text { Resources, capabilities, competences } \\
\text { Number of alternatives }\end{array}$ & $\begin{array}{l}\text { Brand } \\
\text { Innovativeness } \\
\text { Resources, capabilities, competences }\end{array}$ \\
\hline
\end{tabular}

alternative suppliers and, especially with some of the basic products, it has superior power over the Supplier. The Retailer wants to maintain its predominant power position: "We do not see Supplier $A$ as a possible partner for strategic collaboration because the company is too small. Our partners should have a turnover that is high enough, they should be market leaders in their business area, and have strategic capabilities and competences that create unique value." Because of the Retailer's dominant power position there is no collaboration between them. In this relationship the network effects do not play a key role because the Retailer is so powerful. However, many of the Retailer's power sources are actually based on its position and role in the network. These networkrelated sources of power, other organizational power sources and relationship level sources form the constellation of the Retailer's sources of power and lead to a dominant power position.

\subsection{Relationship 2: Retailer and Manufacturer}

The relationship between the Retailer and the Manufacturer has a long history and they both see each other as important partners. In fact, both of them have categorized their relationship as a strategic partnership. However, trust-based collaboration, open information sharing and joint development are still quite shallow in nature, mainly because of the power imbalance. According to the Manufacturer, "The Retailer is reluctant to share its market knowledge," and it uses information to increase its power. The Retailer does not have substitutive suppliers for all of the Manufacturer's products. The Manufacturer, on the other hand, is forced to sell its products to the Retailer because of the Retailer's network role and position. As the Manufacturer admitted, "We are dependent on the retailer." The Retailer's turnover is ten times higher than that of the Manufacturer and the amount of its purchases from the Manufacturer are only a few per cent of the Retailer's turnover, whereas the Manufacturer's sales to the Retailer represent one quarter of the Manufacturer's turnover.

The Manufacturer is willing to develop the relationship, but the Retailer is quite satisfied with the current situation and wants to keep its dominant power position; therefore the power imbalance prevents deeper collaboration. The Retailer's network position and role affect the relationship because the Manufacturer is dependent on its buying volume (Table 3). Thus the Retailer's power sources

Table 3. Power relation between the Retailer and the Manufacturer

\begin{tabular}{|c|l|l|l|}
\hline Relationship 1 & \multirow{2}{*}{ Power Situation } & \multicolumn{1}{|c|}{ Buyer Power Sources } & \multicolumn{1}{c|}{ Supplier Power Sources } \\
\hline Retailer>Manufacturer & \multirow{2}{*}{ Buyer dominance } & Market power, size & Resources, capabilities, competences \\
& & Control of the distribution channel & Brand \\
& & Knowledge about ready-prepared food \\
& & Amount of purchases & Market and customer knowledge \\
& & Customer preference knowledge & Product development, \\
& & Network position, network role & Expertise \\
& & Resources, capabilities, competences & \\
& & & \\
& & & \\
\hline
\end{tabular}


which are related to the network are in key role when defining the nature of the relationship. However, the Retailer is willing to collaborate with the Manufacturer at some level and, therefore, there is some collaboration between them even if the collaboration could be more intensive.

\subsection{Relationship 3: Manufacturer and Supplier A}

The relationship between the Manufacturer and Supplier A (Table 4) has collaborative characteristics, and the Manufacturer is not in such a predominant power position as the Retailer. The amounts of purchases and sales between them are not quantitatively significant in terms of their turnover, and therefore, Supplier A is not highly dependent on the Manufacturer's purchases. However, the Manufacturer has some level of power over the Supplier in that there are not so many manufacturers of ready-made meals but several suppliers of the necessary raw materials. According to Supplier A, "The Manufacturer is not willing to allow us to be part of its product development and it is reluctant to share any other information than is necessary for transactions." Supplier A continued "We would like to have more intensive collaboration." However, on some level the Manufacturer is willing to collaborate because the Supplier's ingredients are significant to its products and it could achieve benefits through collaboration. According to the Manufacturer, "The relationship with Supplier A could be developed further because there is a good basis for collaboration." The Manufacturer does not have superior power over the Supplier, which increases its willingness to collaborate. The only strategically important difference between their power sources is the Manufacturer's role and position in the network, which gives it a slightly better power position. Hence, in this relationship the network effects clearly play a central role because they crucially determine the power relation between them.

\subsection{Relationship 4: Manufacturer and Supplier B}

As Table 5 shows, the Manufacturer and Supplier B are in balanced power positions. The Manufacturer's purchases from the Supplier represent less than one

Table 4. Power relation between the Manufacturer and Supplier A

\begin{tabular}{|c|l|l|l|}
\hline Relationship 1 & Power Situation & \multicolumn{1}{|c|}{ Buyer Power Sources } & \multicolumn{1}{c|}{ Supplier Power Sources } \\
\hline Manufacturer>Supplier A & Buyer dominance & Buyer dominance & Innovativeness, product development \\
& & Network position, network role & Delivery times, level of costs and quality \\
& & Resources, capabilities, competences \\
& & Brand of information & Number of alternatives \\
& & Resources, capabilities, competences & \\
& & & \\
& & & \\
& & & \\
& & &
\end{tabular}

Table 5. Power relation between the Manufacturer and Supplier B

\begin{tabular}{|c|c|c|c|}
\hline Relationship 1 & Power Situation & Buyer Power Sources & Supplier Power Sources \\
\hline Manufacturer=Supplier B & Balanced power & $\begin{array}{l}\text { Network role } \\
\text { Activities connected with others } \\
\text { Resources, capabilities, competences } \\
\text { Number of alternatives }\end{array}$ & $\begin{array}{l}\text { Knowledge about packaging and } \\
\text { packaging materials } \\
\text { Product development, innovativeness } \\
\text { High quality } \\
\text { Resources, capabilities, competences } \\
\text { Number of alternatives }\end{array}$ \\
\hline
\end{tabular}


per cent of its turnover, nevertheless it considers the Supplier important because it purchases considerably more from it than from its competitors. The Manufacturer has alternative suppliers and the Supplier has alternative buyers, thus the actors are not dependent on each other. The relationship is nevertheless significant for both of them. According to Supplier B, "We have a collaborative relationship with the Manufacturer and we have joint projects in product development," and as the Manufacturer put it, "We have joint projects with Supplier B because it is important to us that their products are suitable for our needs." This relationship is clearly based on intensive collaboration. Because the actors do not have network-related power advantages and their power positions are in balance, they do not have the opportunity to dominate and, hence, they have a good basis for collaboration. Moreover, they are willing to collaborate because the relationship is significant for both of them.

\subsection{Concluding the power situations in the case relationships}

The relationship between the Retailer and Supplier A ( R1 = relationship 1 in Figure 3$)$ clearly represents a relationship where the buyer has power over the supplier and there is no collaboration between them. Similarly, the relationship between the Manufacturer and Supplier A (R3) is characterized by buyer dominance, but this relationship is quite close to the

Figure 3. Power and collaboration in the case relationships

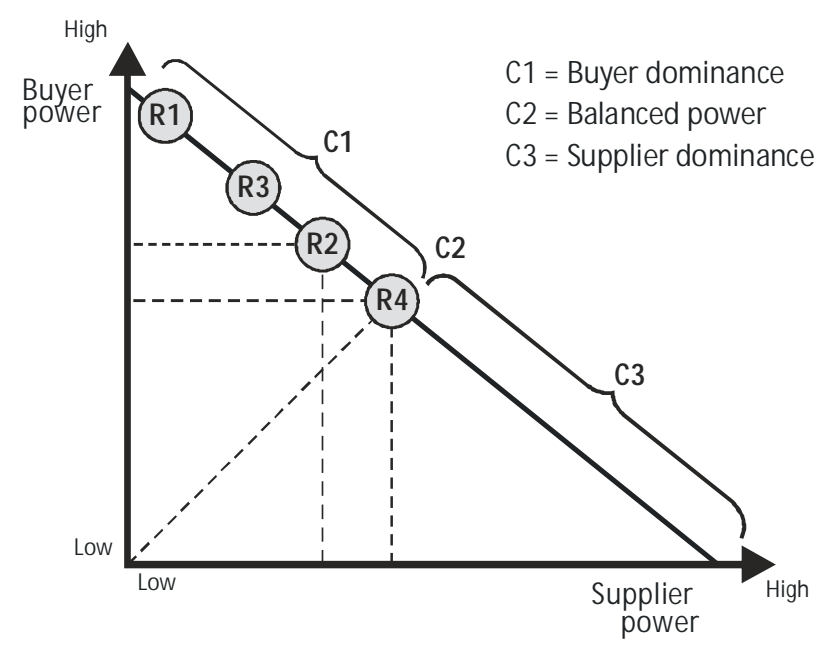

situation where intensive collaboration could be done. The reason for this is the fact that Figure 3 presents the situations in a simplified manner and it has to be acknowledged that power is not the only factor that affects the relationships. For example, the actors' willingness to collaborate plays a key role when determining the nature of the relationship. If both of the actors are willing to collaborate, the relationship in question does not unambiguously fit into the graph of Figure 3. This kind of situation is pushing the relationship towards the proportion of collaboration. This means that the marker of R3 could be moved somewhat lower towards that of $\mathrm{R} 4$ which represents the relationship between the Manufacturer and Supplier B who are in balanced power positions and collaborating.

\section{Conclusions and Discussion}

This study discussed the role of power in buyersupplier relationships in the network context. The aim of the study was to find out how power position in a network affects the nature of collaboration between a buyer and supplier. The theoretical study showed that when parties are in balanced power positions, collaboration is possible because the circumstances support it. However, if the actors are unequal in power, the one that has the dominant position may not be willing to commit to collaboration. Hence, it can be argued that the actors' power position affects the character and depth of the relationship.

Based on previous research (e.g., Anderson et al., 1994; Blankenburg Holm et al., 1996 and 1998; Choi \& Wu, 2009; Dubois \& Fredriksson, 2008; Halinen \& Törnroos, 1998; Veludo et al., 2006) the network as a context in which the relationships exist was highlighted and the actors' network positions were argued to be in key roles. The network context turned out to be significant in that the secondary sources of structural power that emanate from network effects and are related to other network participants beyond the dyadic relationship may crucially determine the power relation between two actors. By showing the significance of the network context, the findings support the insights of Stannack (1996), Cendon and Jarvenpaa (2001) and Zolkiewski (2001) who demanded for the research of power in networks. 
This study broadened the discussion on the buyer-supplier dyad into the wider perspective of networks and analyzed the impact of network effects on power relations. Veludo et al. (2006) have found that influences within the network context are driven by the industry rather than a single organization. This phenomenon was evident also in the case study of this research. The case study discussed power and collaboration in the Finnish food industry network, and the results showed that the structure of the food industry affects the power positions of the actors. The food industry is typically characterized by a high level of retailer concentration, and the Finnish food industry is no exception. The power position and dominance of the Retailer of this case study was significantly based on its role and position in the network. Also the relationship between the Manufacturer and Supplier A was affected by the network context because the network effects moved the power situation in the way that the Manufacturer gained a more powerful position than Supplier A. Hence, it can be argued that the network effects have an influence on power relations.

A very interesting conclusion can be made from the case study and Figure 3 which clearly shows that in every case relationship the buyer has more power than the supplier. The only exception was the relationship between Supplier B and the Manufacturer. Hence, it could be stated that the actors who are in the buyer roles are in dominating power positions in the network. Furthermore, it seems that power increases as the distance from the end-markets decreases, and the closer the firm is to the consumers, the more power it has. The findings also show that when the actors are not equal there are implications with regard to the collaboration. The actors in the case network were willing to form collaborative relationships when they were in the supplier role, but far less willing when they were in the role of the buyer. This was clearly evident in the case of the Manufacturer, whose willingness to collaborate was dependent on its role and power position.

Single-case research such as this does not purport to produce findings that can be generalized in a statistical sense, but as Yin (2003) suggests, they will be valuable in the analytical sense if they clarify or extend understanding of the existing theory. This study enhances understanding of the dynamics of networks in relation to power relations and collaboration. It also has practical implications in terms of revealing the critical factors influencing collaboration, making it possible for managers to focus on relevant factors in developing business relationships.

Further research should be directed especially towards power in networks. There is a need for comparable studies of power relations and networks in other fields as well: it would be useful to find out whether power relations have the same dynamics in other industries. One approach would be to use quantitative research methods, and it would therefore be interesting to conduct an extensive survey on power and collaboration in the network context.

\section{References}

Ahtonen, A-K. (2008), The influence of power on the depth of collaboration. Proceedings of the 24th IMP Conference, Uppsala, Sweden.

Ahtonen, A-K., Kaurijoki, M., Kuusela, H., and Virolainen, V-M. (2008), The influence of power on collaboration. Proceedings of the 17th International Annual IPSERA Conference, Perth, Australia.

Andersen, P.H., and Christensen, P.R. (2005), Bridges over troubled water: suppliers as connective nodes in global supply networks. Journal of Business Research 58 (9), pp. $1261-1273$.

Anderson, H., Havila, V., Andersen, P., and Halinen, A. (1998), Position and role - conceptualizing dynamics in business networks. Scandinavian Journal of Management 14 (3), pp. 167 - 186.

Anderson, J.C., Håkansson, H., and Johanson, J. (1994), Dyadic business relationships within a business network context. Journal of Marketing 54 (4), pp. 1 - 15.

Bates, H., and Slack, N. (1998), What happens when the supply chain manages you? A knowledge-based response. European Journal of Purchasing $\mathcal{E}$ Supply Management 4 (1), pp. $63-72$.

Batt, P.J., and Purchase, S. (2004), Managing collaboration within networks and relationships. Industrial Marketing Management 33 (3), pp. 169 - 174.

Blankenburg Holm, D., Eriksson, K., and Johanson, J. (1996), Business networks and cooperation in international business relationships. Journal of International Business Studies 27 (5), pp. 1033 - 1053.

Blankenburg Holm, D., Eriksson, K., and Johanson, J. (1999), Creating value through mutual commitment to business network relationships. Strategic Management Journal 20 (5), pp. 467 - 486.

Blau, P.M. (1964), Exchange and Power in Social Life, John Wiley, New York. 
Cendon, B.V., and Jarvenpaa, S.L. (2001), The development and exercise of power by leaders of support units in implementing information technology-based services. Journal of Strategic Information Systems 10 (2), pp. 121 158.

Choi, T.Y., and Wu, Z. (2009), Taking the leap from dyads to triads: Buyer-supplier relationships in supply networks. Journal of Purchasing \& Supply Management 15 (4), pp. $263-266$.

Collins, A., and Burt, S. (1999), Dependency in manufacturer-retailer relationships: The potential implications of retail internationalisation for indigenous food manufacturers. Journal of Marketing Management 15, pp. $673-693$.

Cox, A. (2007), Transactions, power and contested exchange: Towards a theory of exchange in business relationships. International Journal of Procurement Management 1 (1/2), pp. 38 - 59.

Cox, A., Sanderson, J., and Watson, G. (2001), Power regimes: A new perspective on managing in supply chains and networks. Proceedings of the 10th International Annual IPSERA Conference, Jönköping, Sweden.

Dubois, A., and Araujo, L. (2007), Case research in purchasing and supply management: Opportunities and challenges. Journal of Purchasing \& Supply Management 13 (3), pp. 170 - 181.

Dubois, A., and Fredriksson, P. (2008), Cooperating and competing in supply networks: Making sense of a triadic sourcing strategy. Journal of Purchasing $\mathcal{E}$ Supply Management 14 (3), pp. 170 - 179.

Doz, Y.L., and Hamel, G. (1998), Alliance Advantage: The Art of Creating Value through Partnering. Harvard Business School Press, Boston, Massachusetts.

Eisenhardt, K.M., and Graebner, M.E. (2007), Theory building from cases: Opportunities and challenges. Academy of Management Journal 50 (1), pp. 25 - 32.

French, J.R.P., and Raven, B. (1959), The bases of social power, in A. Arbor (ed.), Studies in Social Power, University of Michigan Press, Dorwin Cartwright.

Gadde, L.-E., Huemer, L., and Håkansson, H. (2003), Strategizing in industrial networks. Industrial Marketing Management 32 (5), pp. 357-364.

Gadde, L.-E. and Håkansson, H. (2001), Supply network strategies, John Wiley \& Sons, Chichester.

Halinen, A., and Törnroos, J.- $\AA$. (1998), The role of embeddedness in the evolution of business networks. Scandinavian Journal of Management 14 (3), pp. 187- 205.

Harland, C.M. (1996), Supply chain management: Relationships, chains and networks. British Journal of Management 7 (1), pp. $63-80$.

Hingley, M. (2001), Relationship management in the supply chain. International Journal of Logistics Management 12 (2), pp. $57-71$.
Hingley, M., and Hollingsworth, A. (2003), Competitiveness and power relationships: Where now for the UK food supply chain?. Proceedings of the 19th Annual IMP Conference, 4-6 September 2003, Lugano, Switzerland.

Håkansson, H., (1986), Industrial technological development - A network approach, Croom Helm, London.

Kumar, N. (1996), The power of trust in manufacturerretailer relationships. Harvard Business Review 96 (6), pp. $92-106$.

Kumar, N. (2005), The power of power in supplier-retailer relationships. Industrial Marketing Management 34, pp. $863-866$.

Mohr, J.J., Fisher, R.J., and Nevin, J.R. (1996), Collaborative communication of interfirm relationships: moderating effects of integration and control. Journal of Marketing 60 (3), pp. 103 - 115.

Ogbonna, E., and Wilkinson, B. (1996), Inter-organizational power relations in the UK grocery industry: Contradictions and development. The International Review of Retail, Distribution and Consumer Research 6 (4), pp. $395-414$.

Porter, M.E. (1985), Competitive advantage: Creating and sustaining superior performance. Free Press, New York.

Ramsay, J. (1996), Power measurement. European Journal of Purchasing E Supply Management 2 (2/3), pp. 129 - 143.

Robson, I., and Rawnsley, V. (2001), Co-operation or coercion? Supplier networks and relationships in the UK food industry. Supply Chain Management 6 (1).

Stannack, P. (1996), Purchasing power and supply chain management power - A response to Ramsay's Purchasing Power (1995). European Journal of Purchasing $\mathcal{E}$ Supply Management 2 (1), pp. 47 - 56.

Thorelli, H.B. (1986), Networks: Between markets and hierarchies. Strategic Management Journal 7 (1), pp. 37 - 51.

Veludo, M., Macbeth, D., and Purchase, S. (2006), Framework for relationships and networks. Journal of Business E Industrial Marketing 21 (4), pp. 199 - 207.

van Weele, A J., and Rozemeijer, F.A. (1999), The role of power in partnership relationships: An empirical investigation of current body of knowledge. Proceedings of the 8th International Annual IPSERA Conference, BelfastDublin.

Wilkinson, I.F. (1996), Distribution channel management: Power considerations. International Journal of Physical Distribution E Logistics Management 26 (5), pp. $31-41$.

Wilkinson, I., and Young, L. (2002), On cooperating: Firms, relations and networks. Journal of Business Research 55 (2), pp. $123-132$.

Zolkiewski, J. (2001), The complexity of power relationships within a network. Proceedings of the 17th Annual IMP Conference, Oslo, Norway.

Yin, R.K. (2003), Case study research: Design and methods, Sage Publications, Thousand Oaks, California. 
Anni-Kaisa Kähkönen is a Ph.D. student in Lappeenranta University of Technology, School of Business (supply management), from where she obtained her M.Sc. Her current areas of interest include buyersupplier collaboration, power relations, value nets and supply strategies, especially in the food industry. She is the corresponding author and can be contacted at: anni-kaisa.kahkonen@lut.fi

Katrina Lintukangas, D.Sc (Econ. \& Bus.Adm.), is a researcher and lecturer in Lappeenranta University of Technology, School of Business (supply management). Her research interests include supplier relationship management (SRM), global supply management and international business. 